\title{
Nigerian tourists to South Africa: Challenges, expectations and demands
}

\begin{abstract}
Author:
Ikechukwu O. Ezeuduji ${ }^{1}$

Affiliation:

${ }^{1}$ Department of Tourism Management, School of

Tourism and Hospitality, University of Johannesburg, South Africa
\end{abstract}

Correspondence to: Ikechukwu Ezeuduji

Email:

iezeuduji@uj.ac.za

Postal address:

PO Box 524, Auckland Park

2006, Johannesburg,

South Africa

Dates:

Received: 21 Jan. 2013

Accepted: 21 June 2013

Published: 20 Aug. 2013

How to cite this article:

Ezeuduji, I.O., 2013, 'Nigerian tourists to South Africa:

Challenges, expectations and

demands', Acta Commercii

13(1), Art. \#170, 9 pages.

http://dx.doi.org/10.4102/

ac.v13i1.170

\section{Copyright:}

(C) 2013. The Authors.

Licensee: AOSIS

OpenJournals. This work

is licensed under the

Creative Commons

Attribution License.
Read online:
Orientation: Identification of tourists' needs and finding ways of satisfying them is crucial to any tourism destination.

Research purpose: This paper investigated the challenges, demands and expectations of Nigerian tourists to South Africa.

Motivation for the study: Nigeria, along with other African nations, has been identified as one of the core regional source markets with air links to South Africa. Increasing revenue generated from regional tourism is important to South African Tourism.

Research design, approach and method: Descriptive statistics and Chi-square tests were used to analyse the data collected using a questionnaire survey of 320 Nigerian tourists to South Africa.

Main findings: Results showed that Nigerian tourists visit South Africa mostly for the purposes of business, holiday, visiting friends and relatives, education and medical care. Challenges perceived by these Nigerian tourists visiting South Africa include long waiting time for the visa process in Nigeria, expensive cost of living in South Africa, safety and security problems, not so many airlines to choose from and expensive flight costs. Nigerian tourists mostly expect South Africans to be friendlier and have expectations of linking up with new business partners or performing transactions. They also have a strong demand for shopping, leisure and quality education.

Practical/managerial implications: This study recommends a bilateral tourism relationship agreement between the Nigerian and South African governments to ameliorate the visa process; targeted marketing communications by South African Tourism toward Nigerian tourists based on study results; strong police presence and proper policing in South Africa; air transport liberalisation and low-cost carriers implementation for shared economic growth within the African region.

Contribution/value-add: No former research has specifically identified Nigerian tourists' challenges, expectations and demands whilst visiting South Africa.

\section{Introduction}

In October 2012, a three-day collaborative event between Johannesburg (South Africa) and Lagos (Nigeria) - 'The Tale of Two Cities' - showcasing business, tourism, arts and culture was held in Lagos. It was part of an ongoing initiative for an annual event to be hosted by the two cities. The main focus of this programme is fostering bilateral relations in trade, investment, tourism and civil society; providing some evidence of mutual relations pursuit between South Africa and Nigeria. Phelisa Mangcu, acting Chief Executive Officer of the Johannesburg Tourism Company, hailed Nigeria during this event as being one of the strongest African economies and a valuable continental market for Africa with regard to business, investment, leisure and lifestyle (South African Tourism [SAT] 2012a). Tourism is one of the fastest-growing industries in South Africa (Nieman, Visser \& Van Wyk 2008). Rogerson and Kiambo (2007) stated that the promotion of regional tourism can impact positively on South African tourism development and economy. They suggested critical policy interventions at both national and local levels of governments in order to enhance developmental impacts of regional tourism promotion.

Many African and non-African tourism researchers have analysed the constraints, risks, promoting factors and potential of regional tourism development (such as Breakey, Robinson \& Beesley 2008; Douglas, Lubbe \& Kruger 2012; Henriksen \& Halkier 2009; Jones, Munday \& Roberts 2003; Pike 2007; Rogerson 2011; Rogerson \& Kiambo 2007; Timothy 2003). However, these studies have not evaluated a bilateral tourism relationship between two nations within a region, especially as regards challenges, expectations and demands of tourists from one nation visiting another nation. This study will look into such a bilateral relationship, focusing on Nigerian tourists visiting South Africa. 
As regards South African tourism marketing strategy (SAT 2010), Nigeria, Angola, the Democratic Republic of Congo (DRC), Kenya and Tanzania, amongst others, have been identified as being the core regional source markets with air links to South Africa (SAT 2010). Apart from air link, national markets with an urban population of more than 4 million and arrivals of more than 20000 per annum were other main criteria used by South African Tourism when identifying core regional source markets. During 2011, about $35 \%$ of all African land visitors to South Africa stated that their main purpose for visiting South Africa was shopping (business and personal) and out of the overall African air arrivals to South Africa, about $42 \%$ are business tourists and travellers. About $27 \%$ of African land arrivals and 25\% of African air arrivals to South Africa were visiting friends and relatives, whilst $13 \%$ of African land arrivals and 16\% of African air arrivals were on holiday (SAT 2012b). This shows that shopping, business and holiday are the main reasons for African visitors to go to South Africa. African land markets for South Africa include the neighbouring countries of Mozambique, Swaziland, Lesotho, Zimbabwe, Botswana, Malawi, Namibia and Zambia. The rest of the African countries are classified as African air markets for South Africa. Rogerson and Kiambo (2007) stated that apart from the largest flows of shoppers to South Africa, namely land travellers from neighbouring countries, increasing numbers of shoppers are being recorded from African air travellers to South Africa from countries such as Angola, the DRC, Gabon, Kenya, Nigeria and Senegal. For the African air arrivals to South Africa, business tourists and travellers tend to dominate (SAT 2012b). According to Rogerson (2011), the city visited most often is Johannesburg. African tourists are shaping the geography of urban tourism in Johannesburg as these regional African tourists make up the largest number of tourists in the city (Rogerson 2011). Rogerson then recommended that tourism contribution for urban economic development be maximised as an integral part of strategic planning to position Johannesburg in the global economy as one of Africa's world-class city.

As mentioned earlier, Nigeria has been identified as being one of the core regional source markets to South Africa (SAT 2010). No former research has specifically identified Nigerian tourists' challenges, expectations and demands whilst visiting South Africa. Such a study will help SAT managers to make informed decisions with regard to satisfying Nigerian tourists' needs and expectations and in turn increase revenue generated from Nigerian tourists and return on marketing efforts. Ways of working against these challenges, fulfilling these expectations and satisfying these demands can then be sought. This study will therefore attempt to address these.

\section{Background to the study}

Tourism arrivals in South Africa have grown tenfold since 1990 (SAT 2010). According to SAT (2012b), of the total of 8.34 million foreign arrivals in South Africa for 2011, continental Africa accounted for 6.19 million or $74 \%$, with the majority (70\% of the total) coming from neighbouring countries such as Lesotho, Zimbabwe, Mozambique and Swaziland. This implies that Africa, as at 2011, provided the backbone of South Africa's international tourism arrivals (Rogerson \& Visser 2006; Saayman \& Saayman 2003), especially African air arrivals who stay longer than land arrivals. South African Tourism identified that both the barriers and enablers toward winning its attractive set of markets were air seat capacity, political issues, economic issues (such as unemployment), language issues, visa requirements and marketing spend (SAT 2010). The number of visitor arrivals from Nigeria for 2011 in South Africa was estimated at 64 402, a 37.5\% increase as compared with 46853 arrivals in 2010. The average length of stay for 2011 (SAT 2012b) for all tourists was 8.3 days (land arrivals, 4.9 days; air arrivals, 17.6 days), compared with the average of 10 days which is in line with global trends. Nigerian tourists' average length of stay in South Africa during 2011 was 16.1 days, with their main activities during this time being shopping (95\%), nightlife (84\%) and social activities (47\%).

Nigeria was selected as the 'launch pad' for international tourism marketing of South Africa, because of its large population, wealth and relatively high outbound-tourism flows, suggesting significant future potential (SAT 2010). Of special interest to South African Tourism are market opportunities being presented by Nigeria's expatriate communities and its own special class of the 'hyper-wealthy'. According to South African Tourism (2012b), during 2011, $38.2 \%$ of Nigerian visitors to South Africa were business tourists and travellers, $25.1 \%$ were on holiday, $22.4 \%$ of them visited friends and relatives and the rest visited for other purposes. Marketing South Africa to Nigerian tourists builds on the high rate of business travel between the two nations and the findings from focus groups in Nigeria that South Africa is perceived as being a business and holiday destination (SAT 2010). South African Tourism therefore advertises South Africa to Nigeria with the following slogans: 'South Africa - where business meets pleasure', 'Jet set meets out of this world', 'Deal meets maker - what South Africa offers Nigerian traders', 'Style meets taste' and 'Shop until you drop' (Rogerson \& Kiambo 2007; SAT 2010;). South African Tourism targets the Nigerian market by emphasising South Africa's role as Africa's shopping and fashion hub. The average spend per day for Nigerian visitors in South Africa during 2009 was R1430 (higher than 2009's average foreign tourist spend of R1060) and in 2011 was R840 (lower than the average foreign tourist spend of R1070) (SAT 2012b). These figures show that the average spends per day of Nigerian visitors to South Africa fell between 2009 and 2011. Consumer-needs satisfaction in a destination may lead to higher consumer spending in that destination, hence consumer-focused marketing requires that needs of the consumers be identified and satisfied. This study did not examine directly the reason for this fall in average spend per day, but focused instead on identifying the challenges, expectations and demands of Nigerian tourists to South Africa, toward part-implementation of South Africa's Tourism Growth Strategy challenges (SAT 2010). These may, 
arguably, be part of the underlying factors for this revenue decline from Nigerian tourists for South Africa. This will aid SAT managers in making informed decisions as regards satisfying Nigerian tourists' needs and expectations and, in turn, increasing the revenue generated from Nigerian tourists and the return on marketing efforts.

\section{Regional tourism in South Africa Growth factors, demands and expectations}

Intraregional tourists remain the largest segment of all international tourists in Africa (Ndiaye 2006; Timothy \& Teye 2005). Timothy and Teye (2005:88-89) argued that due to 'the weak air, water and rail transportation systems in Africa, the largest proportion of the intra-regional movements is by road transportation'. The World Tourism Organisation (WTO 2004) projected that, in Africa, intraregional tourism arrivals will rise to $64 \%$ of all international tourism by 2020 (exceeding 50 million travellers), in comparison with 58\% recorded for 1995. The key drivers of this projected increase are expected to be increased income levels and wealth (Rogerson \& Kiambo 2007). The same drivers that promoted mass tourism in the First World are now providing the basis for new tourism in the developing world (Gladstone 2005). Mena, Chon and Alampay (2004:21) reported that in South East Asia, for example, with the increased economic affluence of the 520 million-strong population of the ten ASEAN (Association of South East Asian Nations) countries, an increase in intraregional travel is envisaged. The motivators for both domestic and regional travel include pilgrimage, visiting friends and relatives, business travel and an increasing element of leisure tourism (Gladstone 2005). For Africa, particularly South Africa, researchers have pointed out the potential significance of shopping, education and health as other motivators of regional tourism flows (Donaldson \& Gatsinzi 2005; Mba-Anto 2004; Peberdy \& Rogerson 2003; Rogerson 2006; Rogerson \& Visser 2007; Saayman \& Saayman 2003). South African Tourism targets the Nigerian market, for example, by emphasising South Africa's role as Africa's shopping and fashion hub (Rogerson \& Kiambo 2007; SAT 2010). Regional tourists in the developing world are more likely to patronise informalsector tourism establishments as compared with tourists from Western Europe and the Unites States (Gladstone 2005). Bordering nations to South Africa (in particular Zimbabwe, Mozambique, Botswana and Swaziland) were identified as leading sources of this 'informal sector business tourism' (Timothy \& Teye 2005). This implies that regional tourism offers many opportunities for promoting 'pro-poor tourism' in the developing world, as well as in Africa (Gerosa 2003; Mitchell \& Ashley 2006). However, governments have put much effort into encouraging long-haul international tourism and have thus largely overlooked regional tourism potential (Gladstone 2005). This policy oversight may be part of the prevailing heuristic model of tourism development that is myopic to the dynamics and possibilities of both domestic and regional tourism (Aramberri 2004).
Rogerson and Kiambo (2007) identified four critical factors contributing to the expansion of regional tourism visits to South Africa over the past decade, namely, (1) the emergence of South Africa's new democracy and reintegration into the international economy; (2) the expansion of infrastructure networks, especially for land transport; (3) the improved airtransport links between South Africa and the rest of Africa; and (4) the improved living standards, wealth and incomes for a segment of the population across many African countries. They identified other factors further enabling access to regional tourist flows into South Africa as being (a) easier access for foreign exchange in many African countries; (b) improved telecommunication links and internet connectivity, making travel bookings easier; (c) marketing campaigns launched by South African Tourism and supported further by local economic development initiatives in some of the country's main cities; and (d) certain relaxations in South Africa's immigration and visa regulations for African visitors. An example of a very significant change was the 2005 agreement for the waiver of visas for citizens travelling between South Africa and Mozambique. Douglas et al. (2012) supported a single regional visa for the Southern African Development Community (SADC) nations as a possible way to increase destination's accessibility, visitor numbers and visitor spending. They, however, concluded that this may not be a panacea to the slow development of Southern Africa's regional tourism.

\section{Constraints and challenges}

Although South Africa is acclaimed as being one of the leading international tourism destinations and one of the most visited destinations in Africa, it still has to manage perceptions of travel-related risks which can affect destination choice in a negative manner (Lepp \& Gibson 2011). Lepp and Gibson (2008) found that South Africa is perceived as being similar to other African destinations with regard to travel-related risk, such as political and social instability, economic concerns (e.g. currency instability), cultural and language barriers, poor governance, war, terrorism, disease, crime, unfriendly hosts and primitive conditions. Douglas et al. (2012) found that the issues militating against Southern Africa's regional development as a tourism destination of choice were mainly political and security problems; unhelpful government policy for tourism in the region; and inadequate infrastructure. Although prospective tourists have admitted to having little or no knowledge about Africa, these perceptions persist (Lepp, Gibson \& Lane 2011). If a destination is perceived to be unsafe by tourists, this may affect tourist arrivals adversely. South Africa, amongst the many politically-stable democracies in Africa competing for tourists, has been reported to be most burdened by many risk factors which tourists tend to generalise across the continent (Altbeker 2005). South Africa has continually ranked among the world's most dangerous countries as regards violent crime (Kynoch 2005); however through the successful hosting of the 1995 Rugby World Cup, the 2003 Cricket World Cup and, most recently, the 2010 FIFA World Cup, thereby signalling its modernity, South Africa may have been able 
to reduce travel-related risk perceptions. Lepp and Gibson (2011) stated that the issue of perceived travel-related risks in South Africa is complex and there are, without doubt, many more mitigating factors than sporting mega-events. Their study using a sample of US college students, for example, shows that perceptions of risk with regard to travelling to South Africa remain unchanged after the World Cup (this study classified South Africa from its sample as a moderatelyrisky destination before the World Cup). They went further to suggest that although interest in travel to South Africa remained high, this lack of change in overall perception may be as a result of risk-reducing images of modern South Africa generated by the hosting of successful tournaments being neutralised by the negative change in perceptions of South Africa's development level. The general perception by tourists from outside the African continent that the continent of Africa is a risky destination for tourism (Lepp \& Gibson 2011) may not be received well by African regional tourists to South Africa. This assumption may be due to the fact that they are coming from similar socioeconomic dispensations or, more directly, the cultural proximity and low psychic distance amongst African nations, especially in sub-Saharan Africa.

Mathers and Landau (2007:523) reported a schizophrenic response of South Africans toward other Africans, who are a 'critical component of South Africa's Africanness, mighty consumers, widely touted as criminals, seen as a burden on the state, and deported by the tens of thousands'. Amongst the many issues that must be addressed in order to enable the development of a more enabling policy and administrative environment for African tourists are inefficiencies in longdistance transport, safety and security of tourists, xenophobia in post-apartheid South Africa, a lack of appropriately-priced accommodation, poor internal transport within South Africa, lack of storage facilities, difficulties in getting VAT (value added tax) rebates and problems with customs and visas (Rogerson 2006).

\section{Research method and design}

Contemporary leisure and tourism are often mass phenomena, requiring much involvement from governmental, not-forprofit and for-profit organisations, which rely on quantified information for significant aspects of their decision-making. Questionnaire surveys are an ideal means of getting some of this information (Veal 2011). A respondent-completed structured questionnaire method was used to obtain information from 320 Nigerian tourists who visited South Africa between March and July 2011 in order to investigate the perceived challenges, demands and expectations of these tourists on their visit. Out of these 320 administered questionnaires, 313 completed questionnaires were suitable for analysis. The survey of respondents was done at the Johannesburg OR Tambo International Airport departure halls. These respondents were Nigerian tourists who had visited South Africa, were then departing from South Africa, who were able to relate their experiences in South Africa and who could give accurate responses to the questions posed in the questionnaire. Permission to interview tourists at the departure halls of the International Airport was obtained from the Airports Company South Africa. The respondent completion method was chosen because of its advantages of being cheaper, relatively anonymous and quicker (as departing tourists were surveyed) than interviewer completion; hence more care was needed in the questionnaire design so as to avoid incomplete and frivolous responses (Veal 2006). Airlines leaving for Lagos and Abuja (Nigeria) were targeted. Respondents were asked to complete the questionnaire if they were Nigerian citizens, not living and working in South Africa and were aged 16 years and older. Every third traveller who checked in with the airlines was selected for the survey, thus avoiding bias due to preselection. If this traveller did not meet the requirements of the survey, the next traveller was selected.

Variables used in the questionnaire emanated from the literature review of travel demands, expectations and challenges of regional tourists to South Africa (Donaldson \& Gatsinzi 2005; Gladstone 2005; Kynoch 2005; Lepp \& Gibson 2008; Mathers \& Landau 2007; Mba-Anto 2004; Peberdy \& Rogerson 2003; Rogerson 2006, 2011; Rogerson \& Kiambo 2007; Rogerson \& Visser 2007; Saayman \& Saayman 2003; SAT 2010, 2012b), particularly Nigerian tourists. The researcher's personal knowledge also gave rise to other variables included in the questionnaire (demands regarding wildlife experience, sun and beach experience, urban and rural experience).

The questionnaire was constructed in order to investigate perception heterogeneities amongst tourists. Items were introduced to measure the level of satisfaction regarding the trip to South Africa, rating of goods and services offerings in South Africa, demands and expectations related to the South African visit, visit challenges in South Africa, as well as some sociodemographic characteristics of the tourists and visit patterns. Level of trip satisfaction, rating of goods and services offerings, demand and expectations, visit barriers and difficulties were measured along a 5-point Likert scale (ordinal or ranked variables). The scale ranged from 1 (totally dissatisfied/poor/strongly disagree) to 5 (totally satisfied/excellent/strongly agree). The sociodemographic characteristics of tourists and their visit patterns (profile) were sorted into categorical variables.

SPSS version 20 software was used for statistical analysis (IBM Corporation 2011). The first stage of analysis used descriptive statistics to derive frequency of responses (in percentages). The Chi-square test was used later, at the second stage of data analysis, to reveal relationships between tourist profiles and responses to the other questionnaire items. This later stage focused on identifying relationships between sociodemographic characteristics or visit patterns of tourists versus (1) level of visit satisfaction and rating of goods and services offerings in South Africa, (2) visit demands and expectations and (3) visit challenges. Cessford (2003) and Veal (2006) supported the use of the Chi-square test to check for relationships between nominal and/or categorical 
variables. In this study, ordinal variables were subsequently recoded into nominal variables, for the Chi-square tests. All Chi-square tests were done at a $95 \%$ confidence interval.

\section{Ethical considerations}

Permission to interview tourists at the departure halls of the International Airport was obtained from the Airports Company South Africa. Only respondents willing to complete the questionnaire were recruited for the study. Respondents were assured of the anonymity of their responses.

\section{Trustworthiness}

'External validity' of this research (the extent to which the obtained results can be generalised to a wider population than the sample being studied) increased with the random sampling technique and the relative large sample size of 320 used in this study (of which 313 completed questionnaires were suitable for analysis). However, in social sciences research, absolute validity is never guaranteed (Veal 2011:46). 'Internal validity' (the extent to which this research identifies and measures all relevant variables), is optimised through questionnaire survey (an ideal means of getting quantified information), using variables identified in the literature and variables arising from researcher's personal knowledge (Veal 2011:46). Also, in a social science research, such as this, complete reliability (sameness of results if repeated on a later date, using different respondents) is also a rare case, as this study deals with humans in ever-changing social situations (Veal 2011). Follow-up studies are therefore always necessary in order to keep track of changing human needs.

\section{Results and discussions \\ Sociodemographic characteristics of Nigerian tourists to South Africa}

Table 1 depicts the sociodemographic characteristics of Nigerian tourists to South Africa during the survey period. Some of these results are similar to the findings of South African Tourism (2012b), which stated that the average length of stay for Nigerian tourists in South Africa during 2011 was 16.1 days and that their visits are mainly for business purposes, holiday and visiting friends and relatives. Shopping for personal use was not indicated as being the main purpose of the visit; however, many of these tourists demonstrated a demand for shopping whilst in South Africa, as can be seen later in Table 4, in agreement with Rogerson (2011) and South African Tourism (SAT 2012b). Hence, these results do not give lie to SAT advertisement slogans to Nigerian tourists: 'South Africa - where business meets pleasure', 'Jet set meets out of this world', 'Deal meets maker - what South Africa offers Nigerian traders', 'Style meets taste' and 'Shop until you drop' (Rogerson \& Kiambo 2007; SAT 2010). Most of these Nigerian visitors are selfemployed business people and professionals, who have been qualified by South African Tourism as belonging to expatriate communities and the 'hyper-wealthy' business class, presenting market opportunities (SAT 2010).
The most important primary results for SAT managers were those related to the high levels of Nigerian tourists' satisfaction. In total, about $83 \%$ of them stated that they were totally or mostly satisfied with their visit to South Africa. About $46 \%$ of these tourists were also on a return visit, reinforcing their patronage of South Africa as a tourism destination.

\section{Respondents' level of visit satisfaction and rating of offerings in South Africa}

No research has been conducted to measure how Nigerian tourists generally perceive goods and services offerings in South Africa. Nigerian tourists surveyed by this study rated very highly the attractions, accommodation and goods bought in South Africa (Table 2).

A total of about $97 \%$ of Nigerian tourists rated these attractions as being between good and excellent; about $96 \%$ of Nigerian

TABLE 1: Profile of the respondents ( $n=313)$

\begin{tabular}{|c|c|c|}
\hline Variable & Category & Frequency $(\%)$ \\
\hline \multirow[t]{2}{*}{ Gender } & Male & 63.7 \\
\hline & Female & 36.3 \\
\hline \multirow[t]{6}{*}{ Age group } & $16-24$ & 7.6 \\
\hline & $25-34$ & 27.5 \\
\hline & $35-44$ & 40.2 \\
\hline & $45-54$ & 16.7 \\
\hline & $55-64$ & 6.8 \\
\hline & $>65$ & 1.2 \\
\hline \multirow{2}{*}{$\begin{array}{l}\text { Visited South Africa } \\
\text { before }\end{array}$} & No & 53.9 \\
\hline & Yes & 46.1 \\
\hline \multirow[t]{5}{*}{ Number of visit days } & 1-7 days & 34.5 \\
\hline & $8-14$ days & 26.8 \\
\hline & $15-30$ days & 30.6 \\
\hline & 31 days & 8.1 \\
\hline & $>31$ days & 8.1 \\
\hline \multirow{3}{*}{$\begin{array}{l}\text { Number of times visited } \\
\text { before }\end{array}$} & $1-3$ times & 80.2 \\
\hline & 4 times & 19.8 \\
\hline & $>4$ times & 19.8 \\
\hline \multirow[t]{3}{*}{ Level of visit satisfaction } & Totally or mostly dissatisfied & 1.2 \\
\hline & Neutral & 15.4 \\
\hline & Totally or mostly satisfied & 83.4 \\
\hline \multirow[t]{8}{*}{ Employment status } & Unemployed & 2.0 \\
\hline & Retired & 5.1 \\
\hline & Civil servant & 12.8 \\
\hline & Student & 9.1 \\
\hline & Self-employed & 31.6 \\
\hline & Non-executive sales & 1.7 \\
\hline & Professional & 31.0 \\
\hline & Executive-managerial & 6.7 \\
\hline \multirow[t]{7}{*}{ Purpose of visit } & Visiting friends and relatives & 22.8 \\
\hline & Holiday & 26.4 \\
\hline & Medical care & 3.9 \\
\hline & Business travel - exporting goods & 2.3 \\
\hline & Business travel - importing goods & 5.8 \\
\hline & $\begin{array}{l}\text { Business travel - attending } \\
\text { conference/seminar/ event }\end{array}$ & 37.3 \\
\hline & Shopping- personal & 1.6 \\
\hline \multirow[t]{2}{*}{ Visited as a group } & No & 65.2 \\
\hline & Yes & 34.8 \\
\hline \multirow{2}{*}{$\begin{array}{l}\text { Families (with children } \\
\text { less than } 16 \text { years) }\end{array}$} & No & 84.2 \\
\hline & Yes & 15.8 \\
\hline
\end{tabular}


tourists scored accommodation in South Africa between good and excellent; and $92 \%$ of these tourists rated goods bought in South Africa as being between good and excellent. Whilst value for money of goods and services bought in South Africa achieved a good score from about $82 \%$ of the tourists (again ranging between good and excellent), transport in South Africa was not scored as favourably, only obtaining a rating of between good and excellent from $74 \%$ of the tourists. Whilst these may seem to be favourable results for SAT managers, Rogerson's call to upgrade internal transport facilities in South Africa still needs attention (Rogerson 2006).

Table 3 reveals high rating of goods and services offerings in South Africa amongst male respondents, tourists who are 35 years and older, professionals, tourists who have visited before, tourists who are on holiday and those visiting friends and relatives. However, there is no clear linear relationship between the age group of tourists and their overall level of trip satisfaction. When customers value what they have paid for, this leads to customer satisfaction and may, with time, lead to customer loyalty. This is reflected in the result where it is shown that Nigerian tourists who had visited South Africa before rated accommodation in South Africa more highly than those on their first time visit.

\section{Visitor demands and expectations}

With respect to Nigerian tourists' demands and expectations in South Africa (Table 4), the demand for recreation and leisure, for quality education and for shopping seem to form the top three priorities. The demand for nightlife, for new business networks and for the sun and beach experience form the three lowest priorities. Although these results agree with previous studies (Rogerson \& Kiambo 2007; SAT 2010, 2012b), they disagree with findings (SAT 2012b) which showed that Nigerians visiting South Africa during 2011 showed a strong demand for nightlife (84\%). However, this difference in research results may have emanated from the fact that this study was conducted during the autumn and winter months in South Africa, as opposed to South African Tourism's data which was generated throughout the year (including the spring and summer months). Social activities and nightlife in South Africa have greater appeal during the spring and summer months. Male Nigerian visitors have higher expectations for the South African population to be friendlier, show more interest in the development of new business networks and have a higher demand for sports. Female tourists show a higher demand for the sun and beach experience. Younger Nigerian tourists (between the ages of 16 and 34) have a higher demand for both the sun and beach and the urban experience, as well as sports, whilst older Nigerian tourists ( 35 and above) tended toward the requirement to experience new culture, as well as toward having a more rural and wildlife-orientated experience. The professionals amongst these Nigerian tourists mostly expect the South African population to be friendlier and had a high demand for the rural experience. Business tourists attending conference and events were interested in having a rural experience and in forming new business networks. Business tourists (importing and exporting goods) were also, without doubt, the most interested in shopping and nightlife. These results should also help SAT managers in directing their integrated marketing communications and relationship marketing efforts more effectively toward Nigerian tourists

TABLE 2: Respondents' rating in percentage of goods and services offerings in South Africa $(n=313)$.

\begin{tabular}{lllll}
\hline Offerings & Poor & Acceptable & Good & Very good \\
\hline Accommodation in South Africa & 0.3 & 3.3 & 18.9 & 49.0 \\
Transport in South Africa & 11.4 & 14.1 & 24.9 & 28.5 \\
Attractions in South Africa & 0.3 & 3.1 & 16.2 & 19.9 \\
Goods bought in South Africa & 1.4 & 6.6 & 24.8 & 46.6 \\
Value for money (goods and services) & 2.0 & 16.5 & 40.1 & 45.5 \\
\hline
\end{tabular}

TABLE 3: Sociodemographic characteristics of the respondents versus level of visit satisfaction and rating of goods and services ( $n=313$ ).

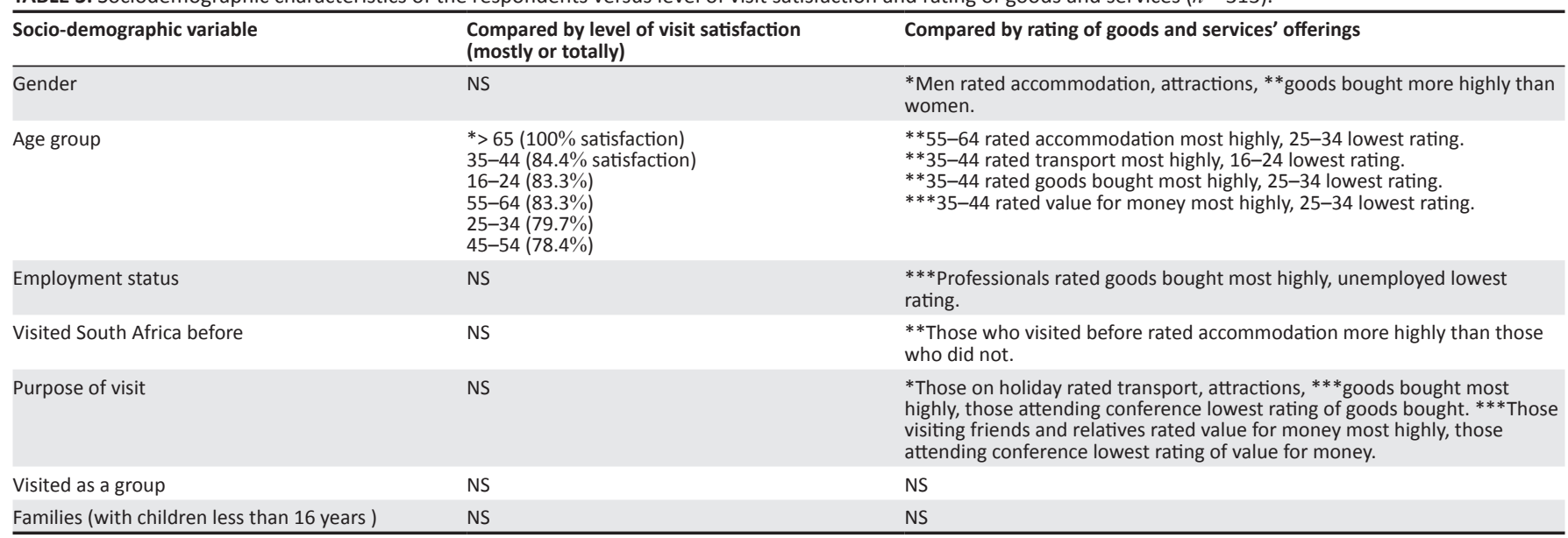

Notes: Pearson Chi-Square test significance.

NS, no significant results.

${ }^{*}, p<0.05 ;{ }^{* *}, p<0.01 ; * * *, p<0.000$ 
to South Africa. More revenue from tourism can be generated when targeted marketing communication is used toward viable tourist market segments.

This study's results agree with previous studies which found visiting friends and relatives, business travel, leisure (Gladstone 2005), shopping, education and health (Donaldson \& Gatsinzi 2005; Mba-Anto 2004; Peberdy \& Rogerson 2003; Rogerson 2006; Rogerson \& Visser 2007; Saayman \& Saayman 2003) to be strong motivators of regional tourism flow in Africa, particularly South Africa.

\section{Visitor challenges}

Table 5 shows that the major challenges perceived by Nigerian tourists to South Africa are long waiting times for the visa process in Nigeria, expensive cost of living in South Africa, fear of crime and of being unsafe, relatively few airlines to choose from, health concerns and expensive flight costs. Long waiting time for the visa process in Nigeria has no relationship with any sociodemographic characteristics. Nigerian tourists who came to South Africa for medical care mostly agree that cost of living in South Africa is expensive, probably due to the high medical cost of their treatment or therapy, which is not particular to South Africa. Most Nigerian tourists on holiday perceive the crime rate to be high and safety a problem. Amongst the perceptions of travel-related risks as outlined by Lepp and Gibson (2008) and Douglas et al. (2012), incidence of crime is the only item that supports these results. Kynoch (2005) also alluded that South Africa has continually ranked amongst the most dangerous countries with regard to violent crime.
It is important to note the score of $22 \%$ of Nigerian tourists (Table 5) who stated that South Africans did not respect them (reality-orientated scoring) and the score of $75 \%$ of these same tourists in Table 4 who expected the South African population to be more friendly (perception-orientated scoring). Tourism destination managers should always distinguish between perception of a conflict and the actual outcome of an experience (Cessford 2003). The perceived travel-related risk of tourists fear of a host nation's population not behaving in a friendly manner towards them as stated by Lepp and Gibson (2008) is supported by this research, however the actual outcome of experience of Nigerian tourists to South Africa shows that $78 \%$ of Nigerian tourists did not agree with the statement 'South African people did not respect me' or declared that it was not applicable to them. This study does, however, support other researchers' views that problems with visas, safety and security of tourists (Douglas et al. 2012; Rogerson 2006) and inadequate infrastructure (Douglas et al. 2012) need to be addressed in South Africa in order to enable the development of a more enabling policy and administrative environment for African tourists.

These results further show that regional tourists in South Africa may not concur with some of the general negative perceptions of African destinations on the part of Western tourists (such as primitive conditions and cultural and language barriers) (Lepp \& Gibson 2008). These results also support the view that because regional tourists to South Africa are coming from similar socioeconomic conditions (if not worse) or have cultural proximity and therefore low psychic distance from South Africa, their perception toward

TABLE 4: Sociodemographic characteristics of the respondents versus visit demands and expectations $(n=313)$.

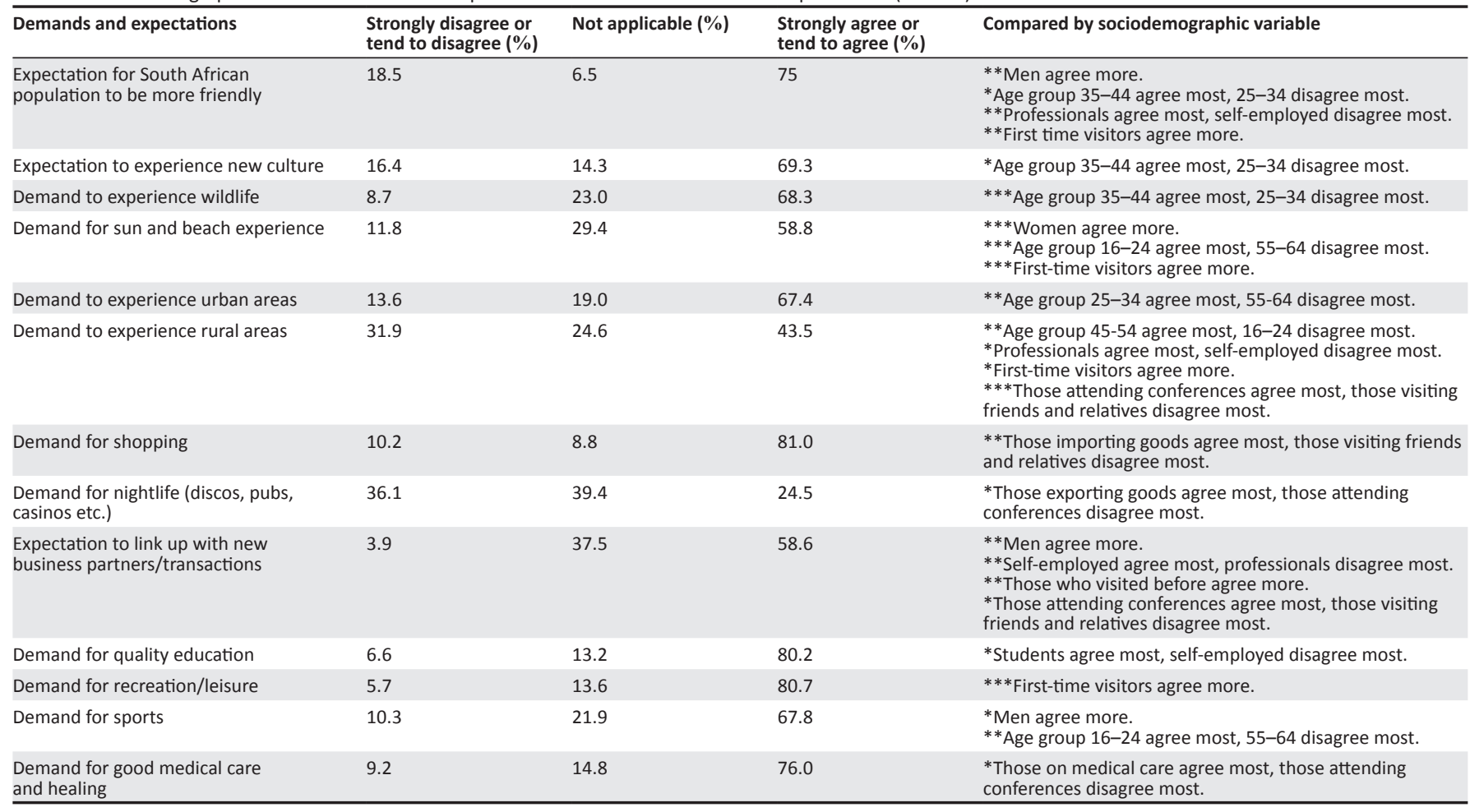


TABLE 5: Sociodemographic characteristics of the respondents versus visit challenges $(n=313)$

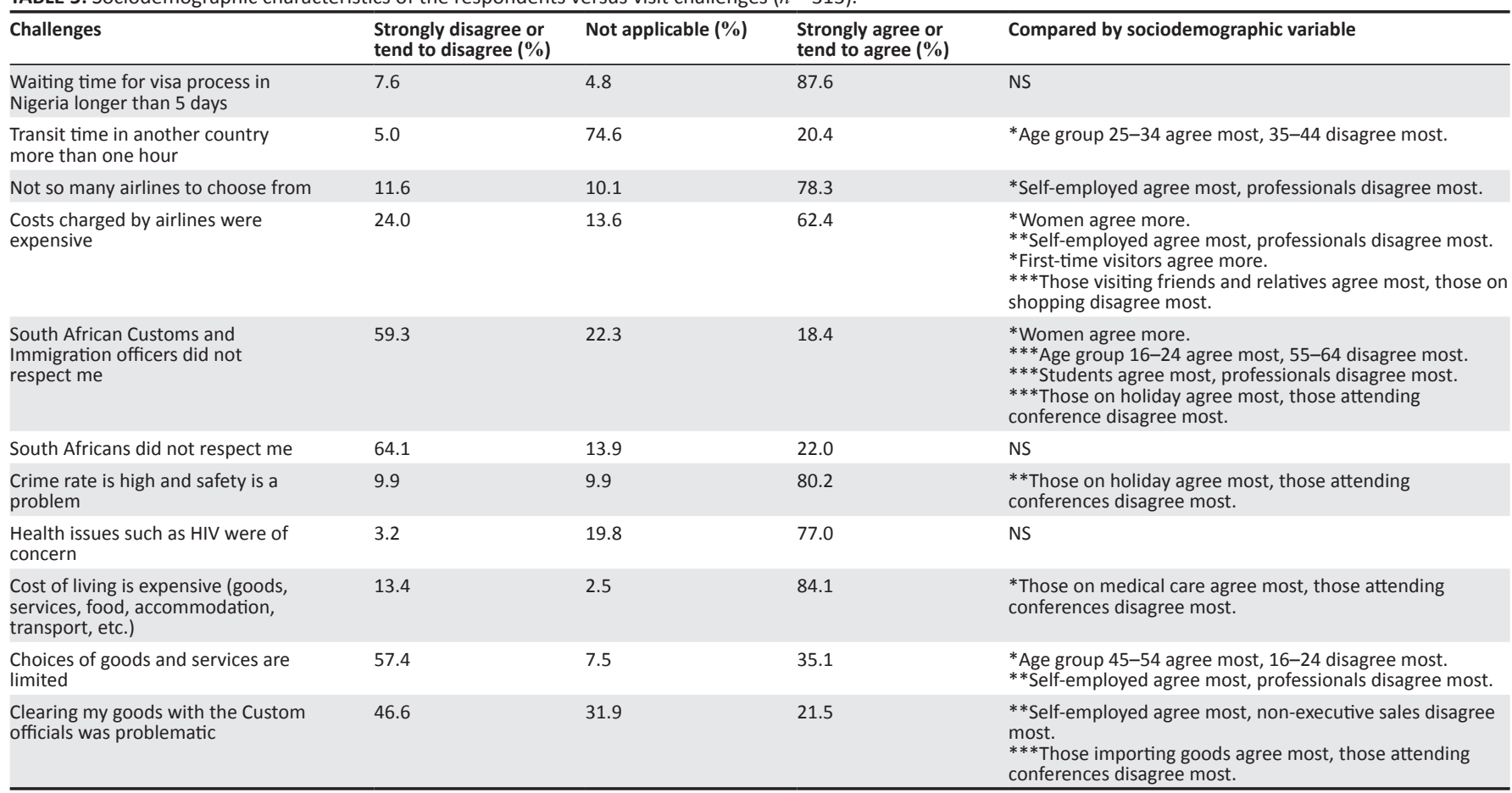

Notes: Pearson Chi-Square test significance.

NS, no significant results.

${ }^{*}, p<0.05 ;{ }^{* *}, p<0.01 ; * * *, p<0.000$

South Africa as a tourism destination is likely to be more favourable than Western tourists.

The problem of a long waiting time for the visa process in Nigeria may be ameliorated through a mutual tourism relationship agreement by the two governments (Nigeria and South Africa), as Nigeria has been identified by South African Tourism (SAT 2010) as being one of its core regional source markets. Online visa application is being used by some African nations already (such as Nigeria and Rwanda) so as to curb inefficiencies in the visa application process. Perceived expensive cost of living by Nigerian tourists to South Africa may be due to a lack of appropriately-priced accommodation, poor internal transport within South Africa and lack of storage facilities for perishable food, as pointed out by Rogerson (2006). The South African government may do well to focus on infrastructure development in order to support tourism development in South Africa. A strong police presence and proper policing in South Africa may give tourists a better feeling of security. It is high time Africa as a region started thinking about the achievement of air transport liberalisation (Rogerson \& Kiambo 2007) and the implementation of low-cost carriers across nations (intraAfrican services) for shared economic growth. This will help stimulate travel demand and encourage middle-class income earners to travel regionally. Implementing this will, of course, involve various stakeholders (such as aviation authorities, national governments, private sector and civil society) in the attempt to stimulate policies that reduce entrant barriers to the airline industry and to curb one of the major constraints of African regional tourism.

\section{Conclusions}

Nigerian tourists to South Africa perceive South Africa generally to be a favourable tourism destination for business travel, holiday, visiting friends and relatives, education and medical care. However, the major difficulties perceived by these Nigerian tourists visiting South Africa include a long waiting time for the visa process in Nigeria, the expensive cost of living in South Africa, safety and security problems, relatively few airlines to choose from and expensive flight costs. Nigerian tourists mostly expect South Africans to be friendlier and have expectations of linking up with new business partners or making business transactions. They also have a strong demand for shopping, leisure and quality education (this last coming from students who travel to South Africa for short courses). This study therefore recommends the institution of a bilateral tourism relationship agreement between the Nigerian and South African governments in order to ameliorate the visa process (for example, trade agreements and the implementation of online visa applications for South Africa); targeted marketing communications by South African Tourism toward Nigerian tourists based on the results of this research (for example, strengthening South Africa's position in advertisements and public relations to the Nigerian market as a friendly business and holiday destination); strong police presence and proper policing in South Africa (for example, instilling the values of zero-tolerance for crime and responsiveness within the South African Police service); air transport liberalisation and implementation of low-cost carriers for shared economic growth within the African region (for example, encouraging the formation of mergers between African airlines and 
attracting new investors to use cost-effective strategies with regard to air transport operation), as various ways to attract Nigerian tourists to South Africa. These conditions are necessary in order to attract more Nigerian tourists to South Africa, as well as probably increasing their spending whilst in South Africa, thereby increasing the generation of revenue from regional tourism. Nigerian students who demand quality education can be attracted to study in South Africa, through exchange programmes that can be made possible by formal partnerships between Nigerian and South African universities. This last recommendation may also attract the students to pursue their postgraduate studies in South Africa.

The limitation of this study is that it was conducted over a three-month period. Nigerian tourists who visit South Africa could be sampled over the whole year (a period of 12 months) in order to obtain more convincing results. That being said, the latter strategy has high costs and the findings over a three-month period could possibly be extrapolated to yield similar results to that obtainable over a 12 -month period.

\section{Acknowledgements}

The author is grateful to Mrs. Amaka S. Ozoani for assisting with the questionnaire survey and the Faculty of Management, University of Johannesburg, South Africa, for financing this research.

\section{Competing interests}

The author declares that he has no financial or personal relationship(s) with other people or organisations that would prevent him from executing and publishing unbiased research.

\section{References}

Altbeker, A., 2005, 'Is South Africa really the world's crime capital?', SA Crime Quarterly 11, 1-8.

Aramberri, J., 2004, 'Domestic tourism in Asia: Some ruffle and flourish for a neglected relation', Tourism Recreation Research 29(2), 1-11.

Breakey, N.M., Robinson, R.N.S. \& Beesley, L.G., 2008, 'Students go a "Waltzing Matilda" - A regional tourism knowledge exchange through innovative internships', Journal of Teaching in Travel \& Tourism 8(2-3), 223-240.

Cessford, G., 2003, 'Perception and reality of conflict: Walkers and mountain bikes on the Queen Charlotte Track in New Zealand', Journal for Nature Conservation 11(4), 310-316. http://dx.doi.org/10.1078/1617-1381-00062

Donaldson, R. \& Gatsinzi, J., 2005, 'Foreign students as tourists: Educational tourism, a market segment with potential', Africa Insight 35(3), 19-24.

Douglas, A., Lubbe, B.A. \& Kruger, E.A., 2012, 'Would a single regional visa encourage tourist arrivals in southern Africa?', Development Southern Africa 29(3), 488-505. http://dx.doi.org/10.1080/0376835X.2012.706042

Gerosa, V., 2003, 'Tourism: A viable option for pro-poor growth in Africa? Pro-poor growth strategies in Africa', Addis Ababa: United Nations Economic Commission for Africa, viewed 05 December 2012, from http://www.tanzaniagateway.org/ docs/pro-poor_growth_strategies in africa_tourism.pdf

Gladstone, D.L., 2005, From pilgrimage to package tour: Travel and tourism in the third world, Taylor \& Francis, Abingdon.

Henriksen, P.F. \& Halkier, H., 2009, 'From local promotion towards regional tourism policies: Knowledge processes and actor networks in North Jutland, Denmark', European Planning Studies 17(10), 1446-1462. http://dx.doi. org/10.1080/09654310903141631

IBM Corporation, 2011, IBM SPSS Statistics for Windows, Version 20.0, IBM Corp., Armonk, N.Y.
Jones, C., Munday, M. \& Roberts, A., 2003, 'Regional tourism satellite accounts: A useful policy tool?', Urban Studies 40(13), 2777-2794. http://dx.doi. A useful policy tool?', Urban Stud
org/10.1080/0042098032000146894

Kynoch, G., 2005, 'Crime, conflict and politics in transition-era South Africa', African Affairs 104(416), 493-514. http://dx.doi.org/10.1093/afraf/adi009

Lepp, A. \& Gibson, H., 2008, 'Sensation seeking and tourism: Tourist role, perception of risk and destination choice', Tourism Management 29(4), 740-750. http:// dx.doi.org/10.1016/j.tourman.2007.08.002

Lepp, A. \& Gibson, H., 2011, 'Tourism and World Cup football amidst perceptions of risk: The case of South Africa', Scandinavian Journal of Hospitality and Tourism 11(3), 286-305. http://dx.doi.org/10.1080/15022250.2011.593361

Lepp, A., Gibson, H. \& Lane, C., 2011, 'Image and perceived risk: A study of Uganda and its official tourism website', Tourism Management 32(3), 675-684. http:// dx.doi.org/10.1016/j.tourman.2010.05.024

Mathers, K. \& Landau, L., 2007, 'Natives, tourists, and makwerekwere: Ethical concerns with "Proudly South African" tourism', Development Southern Africa 24(3), 523-537. http://dx.doi.org/10.1080/03768350701445632

Mba-Anto, F., 2004, 'An investigation of regional tourism to South Africa: The case of Cameroonian and Gabonese tourists', unpublished MA Thesis, School of Geography, Archaeology and Environmental Studies, University of the Witwatersrand.

Mena, M.M., Chon, K. \& Alampay, R.B.A., 2004, 'Discovering the potentials of domestic tourism in Southeast Asia from the perspectives of regional demography', Tourism Recreation Research 29(2), 13-24.

Mitchell, J. \& Ashley, C., 2006, 'Can tourism help reduce poverty in Africa?', Briefing Paper. Overseas Development Institute, London, viewed 02 December 2012, from http://www.odi.org.uk/sites/odi.org.uk/files/odi-assets/publications-opinionfiles/2594.pdf

Ndiaye, O., 2006, 'International tourism trends at the world level and in Africa', Paper presented at UNWTO Workshop on Sustainable Tourism Development and Poverty, 5-7 July, Tangier, Morocco.

Nieman, G., Visser, T. \& Van Wyk, R., 2008, 'Constraints facing tourism entrepreneurs in South Africa: A study in the Gauteng and Mpumalanga provinces, South Africa', Development Southern Africa 25(3), 283-296.

Peberdy, S. \& Rogerson, C.M., 2003, 'South Africa: Creating new spaces?', in R. Kloosterman \& J. Rath (eds.), Immigrant entrepreneurs: Venturing abroad in the age of globalization, pp. 79-99, Berg, Oxford.

Pike, S.D., 2007, 'Repeat visitors - An exploratory investigation of RTO responses', Journal of Travel \& Tourism Research Spring, 1-13.

Rogerson, C.M., 2006, 'Urban tourism in Africa: Shopping in "Jobai", South Africa', Paper prepared for the ATLAS Annual Conference, September, Lodz, Poland.

Rogerson, C.M., 2011, 'Urban tourism and regional tourists: Shopping in Johannesburg, South Africa', Tijdschrift voor Economische en Sociale Geografie 102(3), 316-330. http://dx.doi.org/10.1111/j.1467-9663.2011.00666.x

Rogerson, C.M. \& Visser, G., 2006, 'International tourist flows and urban tourism in South Africa', Urban Forum 17(2), 199-213. http://dx.doi.org/10.1007/s12132006-0005-8

Rogerson, C.M. \& Kiambo, W., 2007, 'The growth and potential of regional tourism in the developing world: The South African experience, Development Southern Africa 24(3), 505-521. http://dx.doi.org/10.1080/03768350701445608

Rogerson, C.M. \& Visser, G., 2007, 'Tourism research and urban Africa: The South African experience', in C.M. Rogerson \& G. Visser (eds.), Urban tourism in the developing world: The South African experience, pp. 13-40, Transaction, New Brunswick, NJ.

Saayman, M. \& Saayman, A., 2003, 'International and African tourism markets for South Africa: An economic analysis', Africa Insight 33(1/2), 93-98.

SAT (South African Tourism), 2010, 'The marketing tourism growth strategy for South Africa 2011-2013', South African Tourism Strategic Research Unit, Johannesburg.

SAT (South African Tourism), 2012a, 'Tourism, trade and investment on the agenda at Johannesburg/Lagos event', viewed 23 November 2012, from http://www. southafrica.net/meetings/en/news/entry/news-trade-tourism-trade-andsouthafrica.net/meetings/en/news/entry/news
investment-on-the-agenda-at-johannesburg-lagos

SAT (South African Tourism), 2012b, '2011 Annual Tourism Report', South African Tourism Strategic Research Unit, Johannesburg, viewed 20 December 2012, from http://www.southafrica.net/uploads/legacy/1/528609/2011_Annual_Report v9_06072012.pdf

Timothy, D.J., 2003, 'Supranationalist alliances and tourism: Insights from ASEAN and SAARC', Current Issues in Tourism 6(3), 250-266. http://dx.doi. org/10.1080/13683500308667956

Timothy, D.J. \& Teye, V.B., 2005, 'Informal sector business travellers in the developing world: A borderlands perspective', Journal of Tourism Studies 16(1), 82-92.

Veal, A.J., 2006, Research methods for leisure and tourism: A practical guide, 3rd edn., Pearson, Essex.

Veal, A.J., 2011, Research methods for leisure and tourism: A practical guide, 4th edn., Pearson, Essex.

WTO (World Tourism Organisation), 2004, 'Vision 2020', WTO, Madrid, viewed 20 December 2012, from http://pub.unwto.org/WebRoot/Store/Shops/Infoshop/ Products/1179/1179-1.pdf 